\title{
J 110
}

\section{社内祅トワークを利用した健康支援（第 2 報）}

\section{NTT 福岡健康管理センタ ○石井昭子 山口文子 佐々木まゆみ}

NTT サイバーソリューション研究所坪井俊明

【はじめに】近年、I T技術の飛躍は目覚しく、グ ローバルなネットワークの有効活用が推進されてい る。前回我々は平成 12 年度定期健康診断結果の有効 活用を目的に保健指導の一環として社内ネットワー クを使用した食事支援をおこない（第 1 報）一定の 成果を上げることができた。今回は、前回の食事支 援に新たにストレス対策、スモークフリー、運動を 加えた 4 つの保健指導プログラムを実施したので報 告する。

【対象】平成 13 年度定期健康診断受検者 3405 名の 中から一事業所を選び、高血圧、高コレステロール 血症、高中性脂肪血症、高血糖、肝機能異常、高尿 酸血症、過体重、貣血のカテゴリにおいて軽度の異 常が認められた 287 名のうち、面談説明にて参加希 望した 248 名（男 239 名、女9名）を対象とした。 【方法】NTT サイバーソリューション研究所が開発 した健康支援システムを使用した。このシステムは ストレス対策、運動、食事、スモークフリーの 4 つ のプログラムで構成され、個々の行動変容のステッ ブ (心理的準備性の段階) に対応して作成されたシ ナリオを電子メールで、6 ケ月間継続的に配信する ものである。開始前に対象者全員に約 15 分の面談 説明を行い、参加の意志を確認した。対象者は基本 問診に答えブログラムの一つを自己選択することが できる。（図 1）配信はストレス対策および食事プロ グラムについては、月に 1 回、運動は実施状況毎に 週 1 回〜月 1 回、スモークフリーは健康意図別に毎 日〜月 1 回行った。各プログラム毎に担当スタッフ を決め、アクセス状況やバィタルレコードの確認を 行い、必要時電話或は、メールでの対応を行った。 自覚症状等の問い合わせに対しては医師が対応した。 【結果及び考察】バーチャル面談による食事支援の 有效性は、第一報で報告したとおりであるが、今回 は 4 つのプログラムの中から、自主選択できること でより対象者の個別性に即した支援が可能となった。
運動プログラムを選択した人の $90 \%$ が新たに運動開 始又はステップを上げながら継続中であり、スモー クフリーでは、参加者の $74 \%$ が現時点では禁煙意志 はないが、禁煙への関心は高いことが判った。又、 禁煙意志がある数名は禁煙開始へと行動変容が認め られた。ストレス対策についてはアンケート調查、 食事については血液検查、体脂肪測定の再検により 効果判定をおこなった。 ネットワークを使用した本支援は、行動変容の認識 が低いと思われる軽度異常者にとって、時間、場所の 拘束がない、また興味あるプログラムを自主決定で きるなと利便性が高い。更に支援者側にとっても、 対象者のアクセス状況を確認しながら適時に指導で きるなど限りあるマンパワーの補助的ツールしても 有効性が高く、更に多くの対象者を同時に支援でき るなど効率性の点からも評価できる。今後は問題点 の改善を図り行動変容のステップアップと定着化に むけて更に検討していきたい。

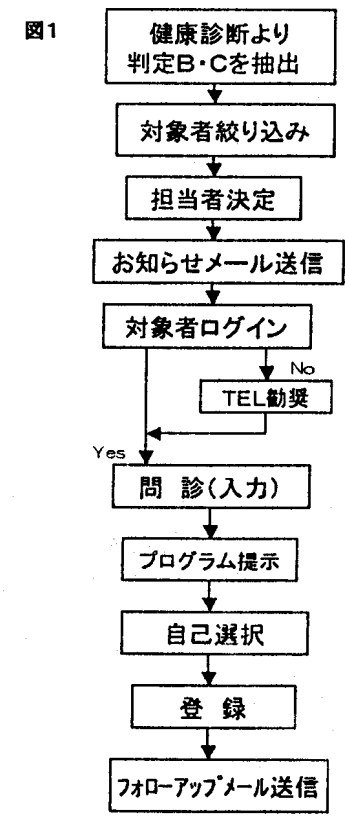

